\title{
Antiretroviral therapy adherence and predictors to adherence in Albania: a cross-sectional study
}

\author{
Shane D Morrison ${ }^{1}$, Vania Rashidi ${ }^{2}$, Clea Sarnquist ${ }^{1}$, Vilson H Banushi ${ }^{3}$, Michael K Hole ${ }^{2}$, Namrata J \\ Barbhaiya $^{2}$, Valbona H Gashi ${ }^{3}$, Lars Osterberg ${ }^{4}$, Yvonne Maldonado ${ }^{1}$, Arjan Harxhi ${ }^{3}$ \\ ${ }^{1}$ Department of Pediatrics, Stanford University School of Medicine, Stanford, CA, United States \\ ${ }^{2}$ Stanford University School of Medicine, Stanford, CA, United States \\ ${ }^{3}$ Department of Infectious Diseases, University of Tirana Faculty of Medicine, Tirana, Albania \\ ${ }^{4}$ Department of Medicine, Stanford University School of Medicine, Stanford, CA, United States
}

\begin{abstract}
Introduction: The possibility of an HIV/AIDS epidemic in southeastern Europe (SEE) is not improbable. Thus, an understanding of the current issues surrounding HIV/AIDS care, specifically antiretroviral therapy (ART) adherence, in countries within SEE is critical. This study was conducted to determine the ART adherence characteristics of Albania's HIV-positive population.

Methodology: This cross-sectional study reports initial demographic and adherence characteristics of patients receiving HIV/AIDS treatment in Albania. Retrospective review of pharmacy medications dispensed supplemented reported adherence behavior. Further, an adherence index was utilized to explore adherence more thoroughly.

Results: Patient-reported adherence and pharmacy review showed adherence levels of $98.9 \pm 4.4 \%$ and $97.7 \pm 4.7 \%$, respectively. Assessment by adherence index revealed an index level of $91.7 \pm 6.7$. Factors associated with a score of $<95$ on the adherence index were: being partnered $(\mathrm{OR}=0.29,95 \% \mathrm{CI}=0.09-0.98)$, history of depression $(\mathrm{OR}=0.24,95 \% \mathrm{CI}=0.08-0.76)$, increased number of barriers to care $(\mathrm{OR}=$ $0.80,95 \% \mathrm{CI}=0.66-0.97)$, and increased number of current social and medical needs $(\mathrm{OR}=0.72,95 \% \mathrm{CI}=0.58-0.91)$.

Conclusions: Interventions aimed at reducing barriers to care, addressing current medical and social needs, and treating mental health issues may help improve adherence to ART in patients with HIV/AIDS in Albania. With little known about HIV/AIDS in SEE, this study provides guidance on how SEE countries can help prevent a possible rise in the prevalence of HIV given the close link of ART adherence and spread of HIV.
\end{abstract}

Key words: Albania; HIV/AIDS; adherence; antiretroviral; survey

J Infect Dev Ctries 2014; 8(7):853-862. doi:10.3855/jidc.3563

(Received 19 March 2013 - Accepted 20 April 2014)

Copyright (C) 2014 Morrison et al. This is an open-access article distributed under the Creative Commons Attribution License, which permits unrestricted use, distribution, and reproduction in any medium, provided the original work is properly cited.

\section{Introduction}

Albania, a country in southeastern Europe (SEE) with 3.2 million people, has thus far avoided the HIV epidemic affecting the majority of Eastern Europe [16]. Albania's HIV prevalence is $<0.1 \%$, as reported by the Albanian Ministry of Health $(\mathrm{MoH})$; through 2013, 671 cumulative HIV cases were reported in Albania [7-9]. However, the $\mathrm{MoH}$ acknowledges the prevalence is likely higher, and a molecular epidemiological study suggests the prevalence may be as high as $1.3 \%$ or 150 -fold that of current estimates [10-18]. The predominant strain of HIV in Albania is HIV-1A, which differs from the many surrounding countries, including Greece, Italy, Serbia, and Montenegro, where epidemics are being driven by HIV-1B [11,19]. The primary mode of transmission within Albania is noted to be through heterosexual contact $[12,13,17]$. The absence of a proper surveillance system, variability in HIV prevalence, and a favorable environment for HIV transmission in a changing Albanian sociopolitical climate make determining the characteristics of an Albanian epidemic essential [19]. Proper interventions can be implemented to avoid further spread of HIV within and outside of Albania by understanding the local epidemic.

Antiretroviral therapy (ART) reduces HIV-related morbidity and mortality, decreases viral load and spread of HIV, and can alter the risky behaviors of HIV-patients [20-29]. Expansion of ART into resource-limited countries has occurred in the last decade, yet coverage is still low in many parts of the world, including Eastern Europe, which only reports $23 \%$ ART coverage [30-34]. It is necessary to assess 
barriers to access to care, and adherence to ART, especially with plans to increase worldwide availability of ART in the coming years and the recent recommendations from the World Health Organization to initiate ART at $\leq 350 \mathrm{CD} 4$ cells $/ \mathrm{mm}^{3}[22,35-38]$. Optimal adherence to ART is recommended to be $\geq$ $95 \%$, as measured by patient recall of ART taken, to help slow progression to AIDS and decrease the risk of ART-resistant strains of HIV [34,39,40]. While there is data that supports the benefits of ART adherence in resource-limited countries, which is generalizable around the globe, there is minimal information on adherence in countries in SEE-the gateway between Eastern Europe and Western Europe, Asia, and Africa. Such deficiencies of data-driven understanding could have profound implications for HIV infection and its epidemiology and treatment $[19,41]$. Knowledge gleaned from studies within these countries could both help prevent further spread of HIV within the given country as well as provide insight into the epidemics in other countries within SEE.

Predictors of adherence to ART have been well documented [34,42-46]. Numerous barriers to care, and current medical and social needs have been demonstrated amongst HIV-positive patients in Albania [47]. This study aims to explore ART adherence in the HIV-positive population in Albania along with determining predictors of and barriers to adherence. The ultimate goal is to gain an initial perspective on adherence through the lens of how potential clinical or policy improvements may mitigate treatment should a larger epidemic arise in this region.

\section{Methodology}

\section{Ethics Statement}

Approval for the study was granted from the Stanford University Institutional Review Board and the Albanian Ethical Committee. Informed written and oral consent was obtained from each participant prior to enrolling in the study.

\section{Study Setting}

The study was undertaken at the University Hospital Center of Tirana (UHCT) HIV/AIDS Ambulatory Clinic, as previously described [10,47]. Since 2004 this clinic has been the sole site offering ART in Albania [13]. ART is given free of charge on a monthly basis, or a bimonthly basis if the patient lives outside of Tirana and must commute to UHCT. At the time of this study ART was initiated when the CD4 count was less than 200 cells $/ \mathrm{mm}^{3}$. This clinic serves the majority of HIV-positive patients in Albania.

\section{Patient Population}

There have been approximately 650 non-pediatric patients that have initiated HIV/AIDS medical treatment at the UHCT HIV/AIDS Ambulatory Clinic since 1994. During the time of this study (June 2009 August 2009), there were 85 patients that received HIV medical care at UHCT, which represented the majority of patients under care at this site during the study time period. Of those, 79 agreed to participate in the study (93\%); 68 of those patients were on ART. Patients unwilling to participate in the study $(n=6)$ were excluded. An on-site psychologist obtained oral and written informed consent in Albanian. Patients were given 400 Leke ( $\sim 5$ USD) for participation.

\section{Survey}

Other parts of the survey used in this study along with the steps taken to ensure proper translation into Albanian were described previously $[10,47]$. The adherence section of the survey was adapted from the survey on adherence from the AIDS Clinical Trials Group (ACTG) (Appendix 1) [48]. This ACTG adherence survey has been validated for use in developing countries and has been shown to perform as well as electronic drug monitors (EDMs) in relating adherence to RNA plasma concentrations of HIV $[49,50]$. The survey was given in the form of semistructured interviews with responses being both multiple-choice and patient generated.

\section{Pharmacy Record Review}

To complement the survey data, a retrospective review of pharmacy records was conducted for each patient. The number of antiretroviral medications prescribed at each of the last three visits was compared to the dates on which the patients came to refill their prescriptions. Patients who came in to refill their ART at $\leq 1$ month, or $\leq 2$ months if the patients lived outside of Tirana, were considered $100 \%$ adherent. Patients that did not return within a month of their last ART refill had their adherence rate calculated by the following formula over three consecutive months:

$$
A=\frac{T_{m}}{T_{v}} \times 100
$$

Where: $\mathrm{A}=$ adherence; $\mathrm{T}_{\mathrm{m}}=\#$ days medication given; $\mathrm{T}_{\mathrm{v}}=\#$ days between visits 


\section{Statistical Methods}

Data was coded and stored electronically. Ten percent of the data was reentered to check for errors; none were identified. Two indices were developed to contribute to the analysis of adherence. These were termed as barriers index, which varied numerically from $0-18$, and a needs index, which varied numerically from $0-9$. Each index number that was assigned to an individual patient was derived from the number of questions answered "yes" in appendix 2 the barriers index is derived from question 2 and the needs index is derived from question 1. For example, if a patient answered yes to needing "HIV medical services" and "assistance with finding meals or food," the patient was assigned a needs index value of two. Each index was then treated as a continuous variable in analysis. The development of the indices along with their parameters was described previously [10, 47]. SAS 9.1.3 was used to analyze the data.

\section{Adherence}

In this study, adherence was defined in two ways. The first method was the percentage of prescribed medications that the patient reported taking over a four-day period. Using this definition, patients were dichotomized into adherent versus non-adherent groups, with adherent being defined as taking $\geq 95 \%$ of the medication doses out of total medication doses prescribed, where $0 \%$ indicates that the patient took none of the medication and $100 \%$ is where the patient took all of the doses of the medication prescribed. The second method is an index, described in-depth below, that includes the parameter of the adherence percentage above, but also includes: how closely the patient followed special instructions, date of the last missed dose, and timing of medication dosage.

Adherence was determined initially from the fourday recall. This standard method for determining adherence is [51]:

$$
A=\frac{D_{p}-D_{m}}{D_{p}} \times 100
$$

Where: $\mathrm{A}$ = adherence; $\mathrm{Dp}=$ prescribed doses; $\mathrm{Dm}$ missed doses;

Adherence for each patient was calculated and aggregated (averaged) for the entire population. The results are expressed in proportions with standard deviations. The method of dichotomization for fourday recall is mentioned above.

A recent principal component analysis of the ACTG 5-item survey showed that this questionnaire correlates better with HIV plasma RNA levels than the four-day recall alone. The questionnaire also correlates better with CD4 counts and predicts adherence similar to EDM. Thus, a multivariable method of analysis to construct an index of adherence was also used $[48,49]$. The formula used to develop the index is [49]:

$$
\begin{aligned}
A=100 \times(0.65+ & (2.15 \times \text { adhd } 1)+(2.21 \times \text { adhd } 2)+(2.07 \\
& \times \text { adhd } 3)+(1.99 \times \text { adhd } 4)+(0.37 \\
& \times \text { follwsch })+(0.36 \times \text { instrfu })-(0.13 \\
& \times \text { lastskip })) / 11.99
\end{aligned}
$$

The variables in the above equation are defined as the following questions in section II of the survey: question 1 (adhd1 - adhd4), question 2 (follwsch), question 3 (instrfu), and question 4 (lastskip). These questions can be seen in appendix 1 . The result of this analysis produced an index from $0-100$ that is not an adherence percentage. The values attained from the index are reported as a mean and associated standard deviation. Ranges and median are also reported. The index was dichotomized so that $\geq 95$ is considered adherent and $<95$ is considered non-adherent. This does not have a specific clinical correlation, but the cutoff for adherence in recall methods is generally set at $\geq 95 \%$; moreover, the higher a patient is on the adherence index the more likely they are to have a lower viral load and higher CD4 count [49]. This dichotomized approach was used to assess variables that are associated with adherence and was not related to a clinically significant cutoff value.

\section{Factors Associated with Adherence}

In determining variables that are associated with adherence, both the four-day recall of medication adherence and the adherence index were used in separate analyses. The dichotomous separation of adherent and non-adherent in both analyses was used due to the severe non-normality of the data. Dichotomization of the four-day recall and adherence index is described above. The association of categorical variables with adherence was evaluated with chi-squared tests unless any cell in the contingency tables had $\mathrm{n}<5$, in which case Fischer's Exact Test was used. For continuous variables, comparisons were done with the t-test or Wilcoxon Rank Sum Test depending on the normality of the data. Factors associated with adherence (in the adherence index) in the crude bivariate analysis with $\mathrm{p}$ $<0.15$ were entered into a multivariable logistic regression analysis that was adjusted for variables that often confound adherence measures: age, gender, and year of education [52]. Adjusted odds ratios with 95\% confidence intervals are reported. Variables were assessed for collinearity before inclusion in the model. 
Table 1. Antiretroviral adherence of patients at UHCT

\begin{tabular}{lc}
\hline Adherence measure & Level of adherence $(\mathbf{n}=\mathbf{6 8})$ \\
\hline Four-day patient recall, mean (SD), \% & $98.9(4.4)$ \\
Median (Range), $\%$ & $100(75-100)$ \\
Pharmacy record review, mean (SD), $\%$ & $97.7(4.7)$ \\
Median (Range), $\%$ & $100(78.6-100)$ \\
Adherence Index *, mean (SD) & $91.7(6.7)$ \\
Median (Range) & $92.7(65.5-100)$ \\
\hline *Adherence Index is defined in the methods section and includes four-day recall, last ART dose missed, and special instructions followed
\end{tabular}

\section{Barriers to Adherence}

The number of patients reporting specific barriers to adherence was reported as a percentage. The barriers were reported in a highest rated barrier order. Possible interventions to increase adherence were also reported in the same fashion.

\section{Persistence}

Pharmacy records were reviewed to determine how many patients on ART at the UHCT HIV/AIDS Ambulatory Clinic during January 2008 - August 2009 missed more than one month of ART. The length of time that patients missed their ART was determined and averaged both with and without patients that were known to have emigrated from Albania.

\section{Results}

Adherence

The average adherence rates differ slightly across the three methods for assessing adherence (Table 1). Adherence measured by the four-day patient recall and the pharmacy review of records were relatively similar, $98.9 \pm 4.4 \%$ and $97.7 \pm 4.7 \%$, respectively. Adherence expressed in the adherence index was $91.7 \pm 6.7$, as is expected from its function in increasing variability of adherence.

When adherence was assessed by four-day recall of medication taken, there were only five patients that were considered non-adherent (Figure 1A). Although non-adherent individuals were few, factors associated with non-adherence include: having a partner (married or cohabiting) $(p=0.05)$, having lived abroad for longer periods of time $(p=0.04)$, having obtained ART abroad ( $\mathrm{p}=0.04)$, and having had the diagnosis of HIV for longer time periods $(\mathrm{p}=0.03)$ (Supplementary Table 1). No further analysis was completed with the four-day recall data because of the limited number of non-adherent respondents. Pharmacy review of ART produced similar results as to the number of patients that were considered nonadherent, thus giving additional validity to the results of the four-day recall adherence measure (Figure 1B).
Figure 1. The dashed-line in the figures distinguishes the adherent group from the non-adherent group. A) Patient adherence to ART based on four-day recall adherence; B) Patient adherence to ART based on pharmacy record; C) Patient adherence to ART as determined by the adherence index. The adherence index takes into account four-day patient recall of medication taken, timing of doses, last missed ART dose, and ability to follow medication instructions.

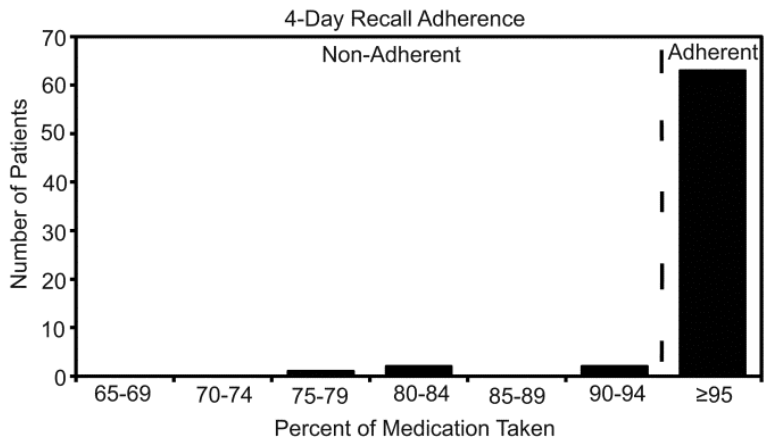

B.

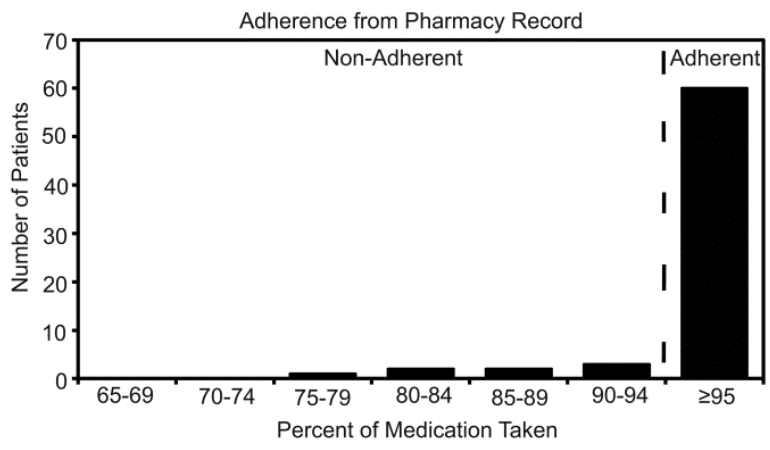

C.

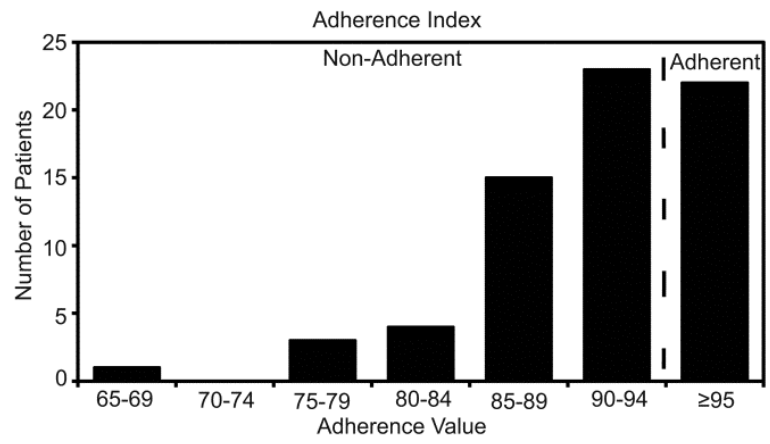


When adherence was assessed with the adherence index, the number of patients considered non-adherent increased to 46 (Figure 1C). Factors associated with non-adherence were: being married as opposed to being single or cohabitating with a sexual partner $(\mathrm{p}=$ 0.04 ), having a history of diagnosed anxiety after diagnosis with HIV $(p=0.05)$, having a history of diagnosed depression after diagnosis with HIV ( $p=$ 0.009 ), having an increased number of barriers to care $(\mathrm{p}=0.03)$, and having an increased number of current social and medical needs $(p=0.0008)$ (Table 2$)$.

In a multivariate logistic regression model with adjustment for age, gender, and years of education, the following factors were associated with a lower odds of being adherent: having a partner (married or cohabitating) $(\mathrm{OR}=0.29,95 \% \mathrm{CI}=0.09-0.98)$, having a history of depression following HIV diagnosis $(\mathrm{OR}=0.24,95 \% \mathrm{CI}=0.08-0.76)$, increasing number of barriers to care $(\mathrm{OR}=0.80,95 \%$ $\mathrm{CI}=0.66-0.97)$, and increasing number of current social and medical needs $(\mathrm{OR}=0.72,95 \% \mathrm{CI}=0.58-$ $0.91)$. The multivariate logistic regression model was adjusted for age $(p=1.00)$, gender $(p=0.71)$, and years of education $(\mathrm{p}=0.07)$ because these factors that

Table 2. Associations of adherence of patients receiving antiretroviral medication at UHCT HIV/AIDS Ambulatory Clinic by adherence index

\begin{tabular}{|c|c|c|c|}
\hline Characteristic & $\begin{array}{c}\text { Adherent } \\
(\mathrm{n}=\mathbf{2 2})\end{array}$ & $\begin{array}{c}\text { Non-adherent } \\
(n=46)\end{array}$ & $P$ Value \\
\hline Age, mean (SD), $y$ & $42.0(14.9)$ & $39.5(9.8)$ & 1.00 \\
\hline Median (Range), $y$ & $40.5(23-79)$ & $38.5(18-64)$ & \\
\hline Female, No. (\%) & $8(36.4)$ & $15(32.6)$ & 0.76 \\
\hline Heterosexual, No. (\%) & $20(90.9)$ & $43(94.5)$ & 0.66 \\
\hline Married, No. (\%) & $7(31.8)$ & $27(58.7)$ & 0.04 \\
\hline Partnered, No. (\%) & $8(36.4)$ & $27(58.7)$ & 0.09 \\
\hline$>$ Higher (12 Classes), No. (\%) & $6(27.3)$ & $4(8.7)$ & 0.07 \\
\hline Muslim, No. (\%) & $16(72.7)$ & $39(84.8)$ & 0.32 \\
\hline Years abroad, mean (SD), $y$ & $2.8(5.0)$ & $2.8(4.8)$ & 0.99 \\
\hline Median (Range), $y$ & $0(0-16)$ & $0(0-17)$ & \\
\hline Obtained ART abroad, No. (\%) & $3(13.6)$ & $2(4.4)$ & 0.32 \\
\hline Years since diagnosis, mean (SD), $y$ & $2.6(2.7)$ & $2.9(3.3)$ & 0.89 \\
\hline Median (Range), $y$ & $2(0-11)$ & $2(0-16)$ & \\
\hline Employed/Student/Retired, No. (\%) & $8(36.4)$ & $23(50.0)$ & 0.29 \\
\hline Arrested $\geq 24$ hours, No. (\%) & $7(31.8)$ & $10(21.7)$ & 0.37 \\
\hline Ever tried drugs, No. $(\%)^{*}$ & $1(4.6)$ & $5(11.1)$ & 0.66 \\
\hline Attained HIV through sexual contact, No. (\%) & $13(59.1)$ & $19(41.3)$ & 0.17 \\
\hline Experienced anxiety after HIV diagnosis, No. (\%) & $15(68.2)$ & $41(89.1)$ & 0.05 \\
\hline Experienced depression after HIV diagnosis, No. $(\%) \dagger$ & $9(42.9)$ & $34(75.6)$ & 0.009 \\
\hline Living with household members with HIV/AIDS, No. (\%)* & $4(18.2)$ & $9(20.0)$ & 1.00 \\
\hline Barrier Index $\ddagger$, mean (SD), \# & $6.5(3.4)$ & $8.4(2.6)$ & 0.03 \\
\hline Median (Range), \# & $7.5(1-13)$ & $9(2-13)$ & \\
\hline Need Index $\S$, mean (SD), \# & $4.6(2.2)$ & $6.8(2.5)$ & 0.0008 \\
\hline Median (Range), \# & $4(1-8)$ & $8(0-9)$ & \\
\hline
\end{tabular}

*22 adherent and 45 non-adherent respondents

$\dagger 21$ adherent and 46 non-adherent respondents

†Barrier Index includes barriers experienced by patients in seeking HIV medical care.

$\S$ Need Index includes current needs that patients are having with regard to medical and daily life

Table 3. Multivariate logistic regression on adherence index analysis $\dagger$

\begin{tabular}{lccc}
\hline Parameter & $\mathbf{O R}^{*}$ & $\mathbf{9 5}$ \% CI & $\boldsymbol{P}$ Value \\
\hline Married† & 0.35 & $0.12-1.03$ & 0.06 \\
Partnered & 0.29 & $0.09-0.98$ & 0.05 \\
Anxiety & 0.28 & $0.07-1.03$ & 0.06 \\
Depression & 0.24 & $0.08-0.76$ & 0.01 \\
Barrier Index & 0.80 & $0.66-0.97$ & 0.02 \\
Need Index & 0.72 & $0.58-0.91$ & 0.005 \\
\hline
\end{tabular}

*Odds Ratio for being considered adherent.

$\dagger$ Adjusted for age, gender, and years of education.

$\$$ Adjustment for gender and years of education. Age is collinear with marriage. 
are common confounders in adherence measures even though two of the factors (age and gender) did not illustrate potential confounding in univariate analysis [52]. Having a history of anxiety or being married was not associated with lower odds of being adherent (Table 3). The multivariate logistic regression model used for marriage was only adjusted for gender and years of education, for age is collinear with marriage.

Of the patients that were on ART from January 2008 - August 2009, 23 patients left therapy for more than one month (Supplementary Table 2). The average time these patients left therapy was $10.4 \pm 4.4$ months. If patients were excluded that were known to have emigrated from Albania, there were 19 patients that left therapy; on average these patients left therapy for $10.4 \pm 4.8$ months.

\section{Barriers to Adherence}

Patients were also asked about reasons for missing doses of medication and about possible interventions that may be useful in improving adherence. In reporting reasons for missed doses of ART, the most common reasons were: simply forgot $(20.6 \%)$, were away from home $(17.6 \%)$, and were busy with other things $(17.6 \%)$ (Supplementary Table 3A). The most difficult barriers to adherence for patients were: being busy with other things $(17.4 \%)$, wanted to eliminate side effects $(13.0 \%)$, ran out of medication $(13.0 \%)$, and simply forgot (13.0\%) (Supplementary Table 3B).

Patients also suggested interventions that could increase the likelihood of not missing any ART doses (Supplementary Table 4A). The most common responses were: more education on the seriousness of HIV/AIDS (37.3\%), more education on the reasons for taking medication $(32.8 \%)$, and not so many pills to take $(25.4 \%)$. The interventions that were the most important to the patients were related to education and attaining medication in close proximity to their homes (Supplementary Table 4B).

\section{Discussion}

Many challenges face patients that are seeking care for HIV/AIDS in Albania, yet this study evidences that once patients reach care, adherence to ART is high $[10,13,14,16-18,47]$. Factors contributing to poor medication adherence include being partnered, mental health issues, higher levels of barriers to care, and higher current medical and social needs.

Participation in this study was high (93\% response rate) and results suggest that once patients are able to access care, they tend to be adherent and persistent to ART. Patients had high levels of adherence on four- day recall, pharmacy review of records, and the adherence index - 98.9 $\pm 4.4 \%, 97.7 \pm 4.7 \%$, and $91.7 \pm 6.7$, respectively (Table 1 ). These high levels of adherence are encouraging since it seems that patients who received care are motivated to be adherent to their ART. Though there tends to be overestimates of adherence in self-reported measures, the four-day recall and pharmacy review of records showed a strong correlation $[48,51,53,54]$. Indeed, with the clinical cutoff for adherence being $\geq 95 \%$ of ART taken, the vast majority of the patients met this criterion on four-day recall and pharmacy review of records. Adherence based on the adherence index was slightly lower, yet there is, as of yet, no known clinically significant cutoff; so an arbitrary value of $\geq$ 95 was chosen as being adherent for analysis purposes. Increasing values in the adherence index is predictive of a lower viral load and increased CD4 count [49]. From these results it may be suggested that the HIVpositive population in Albania is likely to be adherent to ART if they are able to overcome the barriers that prevent them from finding medical care.

When factors associated with adherence were analyzed, results differed slightly between the adherence index and the four-day recall of medication taken (Table 2 and Supplementary Table 1). Based on these comparisons, the only value that seems to overlap is that adherence tends to decrease when patients are married or partnered. Patients may be keeping their HIV status concealed from their partners due to the high levels of social stigma associated with HIV in Albania [10,21,47]. This may offer an avenue for intervention with more in-depth counseling on ART and HIV to patients that are married or with a partner. The other differences in the associations may be attributed to the small number of patients that were considered non-adherent on four-day recall of medication taken. With only five patients being nonadherent, this decreases the potential of being able to generalize the results to the entire HIV-positive population in Albania and the power of the statistical analyses. Therefore, for further analysis with multivariable logistic modeling, the adherence index was chosen.

In multivariable logistic regression modeling that was adjusted for age, gender and years of education, a decreased odds of being adherent was associated with being partnered (married or cohabitating), having a history of depression following diagnosis with HIV, having experienced a higher number of barriers to care, and having a higher number of current medical and social needs (Table 3). This suggests that 
interventions should be aimed at patients that are partnered or have a history of depression. Also, decreasing the barriers to care that are experienced by patients along with assisting with the current medical and social needs of patients may help to increase adherence to ART.

When patients were asked directly about reasons for missing doses of ART, common reasons were related to forgetting or lifestyle changes (Supplementary Table 3). Patients also supported measures to increase education on the seriousness of HIV and the necessity for taking ART as a means to increase adherence (Supplementary Table 4). Though these represent more direct means of increasing adherence through interventions or education, each can be explored if adherence to ART decreases in Albania.

The necessity for interventions aimed at keeping patients adherent to ART and enrolled in HIV medical services is evidenced by the number of patients that left care between January 2008 and August 2009. Therefore, interventions need to be aimed at patients currently enrolled in HIV medical care programs in Albania to prevent loss to follow-up. The mechanisms that lead to these patients missing therapy were not examined in this study.

Limitations of this study include self-report bias and small sample size. In assessing adherence, selfreport methods are commonly used, but tend to be reported as an overestimate [48,51,53,54]. Drug holidays (i.e. not taking medications on weekends) and white-coat adherence (increased adherence before a medical check-up) may also be missed with these measures. Still, self-report methods are used widely in assessing adherence [51]. The correlation between the self-reported adherence and pharmacy review of medications, in this study, offers support for this assessment. The use of the adherence index has also shown to correlate with clinical markers of adherence and was therefore used [49]. The smaller sample size may prevent generalization, yet this study covered the majority of known patients under HIV medical care in Albania during the study period. Results can therefore be expected to apply to patients that are currently attaining care and may inform future patient recommendations.

Of the Albanian HIV-positive population receiving ART treatment, these individuals appear to be largely adherent to ART, yet barriers to care along with medical and social needs are obstacles to patient arrival into the health sector and adherence to ART [47]. Thus, future interventions that may be successful in allowing patients to reach HIV-specialty care in Albania will arise from addressing barriers to care, and medical and social needs of the patient population. This may also have the indirect effect of decreasing transmission of HIV from those affected to those nonaffected given the main mode of transmission of HIV in Albania is heterosexual contact. Of note, more attention needs to be paid to patients that are partnered and/or depressed. Structuring of the healthcare sector to address these issues for HIV-positive patients in Albania may aid in sustaining the low HIV prevalence within this country.

Maintaining or increasing the current levels of ART adherence amongst patients in Albania may also have affects across the Balkans along with neighboring Eastern and Western European countries. The changing sociopolitical climate that has occurred in the Balkans and the postwar recovery phases in many of these countries has left them uniquely susceptible to a rapid growing and undetected HIV epidemic $[19,41]$. Inadequate healthcare infrastructure coupled with the high mobility of these populations offers concern for spread of HIV within and outside of the Balkans, should an epidemic arise. As HIV-1A, the strain most prevalent in Former Soviet countries, is the current dominate strain of HIV in Albania, this is also worrisome to Italy, Greece, Montenegro, Serbia, and other Western European countries where HIV-1B is dominate [11]. Furthermore, the HIV-1B strain is also present in the Balkans and was introduced from multiple sources, resulting in frequent intercountry exchanges and local dispersal, suggesting that the Balkans serves as a gateway between Eastern and Western Europe [19,41]. The introduction of nonpredominant strains in any of these countries/regions, including in Albania itself, may alter the current dynamic of the epidemic and lead to unforeseen problems. If the current levels of adherence are sustained and the government/healthcare structure acts to reduce barriers to care in Albania, some of the aforementioned situations may be avoided. ART adherence along with early diagnosis and treatment has been shown to decrease the likelihood of transmission of HIV, an area that Albania has a unique opportunity to effectively address and potentially become a paradigm for HIV diagnosis and treatment in the Balkans $[24,25,27,29]$. The foundation is laid, but further innovation at the intervention in the clinical and policy levels are necessary to efficiently quell the potential Albanian HIV epidemic. 


\section{Acknowledgements}

The authors thank Dritan Agalliu of Stanford University School of Medicine for translation of the instrument into Albanian; Cynthia Castro of the Stanford Prevention Center for feedback on the development of the project; Pranvera Kulla of the UHCT HIV/AIDS Ambulatory Clinic for help with consenting and recruiting patients for the study; Rita Popat of Stanford University Department of Epidemiology and Biostatistics for statistical advice and consultation; and the staff at the UHCT Infectious Diseases Department and the Stanford University School of Medicine Department of Pediatrics for making this project possible. Support for this study came from the Stanford University Peter Emeg Memorial Medical Scholars Grant to Shane D. Morrison

\section{References}

1. UNAIDS/World Health Organization, (2009) Fact Sheet on Global HIV/AIDS, $2009 . \quad$ Available: http://www.unaids.org/documents/20101123_FS_Global_em en.pdf. Accessed 15 August 2012.

2. European Centre for Disease Prevention and Control/WHO Regional Office for Europe (2013) HIV/AIDS surveillance in Europe 2012. Stockholm. Available: http://www.euro.who.int/_data/assets/pdf_file/0018/235440/ e96953.pdf?ua $=1$. Accessed 23 January $20 \overline{13}$..

3. Cohen J (2010) Late for the epidemic: HIV/AIDS in Eastern Europe. Science 329: 162-164.

4. Jasny B, Mueller K, Roberts L (2010) HIV/AIDS: Eastern Europe. Introduction. Science 329:159.

5. Kilmarx PH (2009) Global epidemiology of HIV. Curr Opin HIV AIDS 4: 240-246.

6. Qyra ST, B.M., Bani R, Dervishi M, Ulqinaku D, Bino S, Harxhi A (2011) Behavorial risk factors and prevalence of HIV and other STIs among female sex workers in Tirana, Albania. The New Microbiologica 34: 105-108.

7. Ministry of Health of Albania (2012) Draft - The National Strategy for the Prevention and Control of HIV/AIDS in Albania 2009-2014 (NSPCHA). Available: http://www.unaids.org/en/dataanalysis/knowyourresponse/cou ntryprogressreports/2010countries/albania 2010_country_pro gress_report_en.pdf. Accessed 15 August 2012.

8. United Nations Office on Drugs and Crime (2012) Ensuring relevant authorities act to contain the HIV/TB/Hepatitis C epidemics among drug users and in prison settings in Albania, Serbia and the FYR of Macedonia. Available: http://www.gesundinhaft.eu/wpcontent/uploads/2008/04/EHRN-Prisons_Projectreport March-2012.pdf. Accessed 23 January 2013.

9. Boci A, Neli G, Wolff K (2011) Explore the risk factors of HIV, Hepatitis Viral B and C and evaluate the prevalence of these infections among prisoners in Tirana - Albania. International Programme in Addiction Studies.

10. Morrison SD, Banushi VH, Sarnquist C, Gashi VH, Osterberg L, Maldonado Y, Harxhi A (2011) Levels of self-reported depression and anxiety among HIV-positive patients in Albania: a cross-sectional study. Croatian medical journal, 52: 622-628.

11. Salemi M, de Oliveira T, Ciccozzi M, Rezza G, Goodenow MM (2008) High-resolution molecular epidemiology and evolutionary history of HIV-1 subtypes in Albania. PLoS ONE 3: e1390.
12. The World Bank (2008).Albania: Key Indicators. Available: http://web.worldbank.org/WBSITE/EXTERNAL/COUNTRI ES/ECAEXT/ALBANIAEXTN/0,,menuPK:301417 pagePK: 141159 piPK:141110 theSitePK:301412,00.html. Accessed 28 July 2010

13. Ministry of Health (Republic of Albania) (2007) Albania Country Progress Report. Available: http://www.al.undp.org/content/dam/albania/docs/MDG\%20R eport2007\%20-\%20english.pdf. Accessed 15 August 2012.

14. Bino S, Rjepaj K, Harxhi A (2006) Albania - Behavioral and Biological Surveillance Study Report. USAID/Ministry of Health (Republic of Albania)/Institute of Public Health. Available:

https://www.globalhivmeinfo.org/DigitalLibrary/Digital\%20L ibrary/Albania\%20-

$\% 20$ Behavioral\%20and\%20Biological\%20Surveillance \%20S tudy\%20Report.pdf. Accessed 28 July 2010.

15. Ciccozzi M, Gori C, Boros S, Ruiz-Alvarez MJ, Harxhi A, Dervishi M, Qyra S, Schinaia N, D'Arrigo R, CeccheriniSilberstein F, Bino S, Perno CF, Rezza G (2005) Molecular diversity of HIV in Albania. J Infect Dis 192: 475-479.

16. UNICEF (2004) Rapid Assessment and Response - Tirana. Available: http://www.unicef.org/albania/hivaidsalbania.pdf. Accessed 28 July 2010.

17. Ministry of Health, Republic of Albania (2003) Let's Keep Albania a Low HIV Prevalence Country: The National Strategy of Prevention and Control of HIV/AIDS in Albania $2004 \quad 2010 . \quad$ Available: http://www.ilo.org/wcmsp5/groups/public/---ed_protect/--protrav/---

ilo_aids/documents/legaldocument/wcms_127395.pdf. Accessed 28 July 2010.

18. Harxhi A, Pernaska L (2002) Rapid Assessment and Response on HIV/AIDS Among Especailly Vulnerable Young People in Albania: A Country Report. UNICEF: Tirana. Available: http://www.unicef.org/albania/hivaidsalbania.pdf. Accessed 28 July 2010.

19. Ciccozzi M, Lai A, Ebranati E, Gabanelli E, Galli M, Mugosa B, Vratnica Z, Vujoševic D, Lauševic D, Ciotti M, Cella E, Lo Presti A, Zehender G (2012) Phylogeographic Reconstruction of HIV Type 1B in Montenegro and the Balkan Region. AIDS research and human retroviruses 28: 1280-1284.

20. Kaida A, Gray G, Bastos FI, Andia I, Maier M, McIntyre J, Grinsztejn B, Strathdee SA, Bangsberg DR, Hogg R (2008) The relationship between HAART use and sexual activity among HIV-positive women of reproductive age in Brazil, South Africa, and Uganda. AIDS Care 20: 21-25.

21. Ministry of Health (Republic of Albania) (2008) Strengthening Albania's National Response to HIV/AIDS among Vulnerable Groups Program. Available: http://www.ishp.gov.al/wpcontent/themes/instituti/pdf/aids.pdf. Accessed 28 July 2010.

22. Boulle A, Ford N (2007) Scaling up antiretroviral therapy in developing countries: what are the benefits and challenges? Sex Transm Infect 83: 503-505.

23. Hacker MA, Kaida A, Hogg RS, Bastos FI (2007) The first ten years: achievements and challenges of the Brazilian program of universal access to HIV/AIDS comprehensive management and care, 1996-2006. Cad Saude Publica 23 Suppl 3: S345-359. 
24. Kennedy C, O'Reilly K, Medley A, Sweat M (2007) The impact of HIV treatment on risk behaviour in developing countries: a systematic review. AIDS Care 19: 707-720.

25. Braitstein P, Brinkhof MW, Dabis F, Schechter M, Boulle A, Miotti P, Wood R, Laurent C, Sprinz E, Seyler C, Bangsberg DR, Balestre E, Sterne JA, May M, Egger M (2006) Mortality of HIV-1-infected patients in the first year of antiretroviral therapy: comparison between low-income and high-income countries. Lancet 367: 817-824.

26. Hogan D, Salomon J (2005) Prevention and treatment of human immunodeficiency virus/acquired immunodeficiency syndrome in resource-limited settings. Bulletin of the World Health Organization 83: 135-143.

27. Murphy EL, Collier AC, Kalish LA, Assmann SF, Para MF, Flanigan TP, Kumar PN, Mintz L, Wallach FR, Nemo GJ (2001) Highly active antiretroviral therapy decreases mortality and morbidity in patients with advanced HIV disease. Ann Intern Med 135: 17-26.

28. Paterson DL, Swindells S, Mohr J, Brester M, Vergis EN, Squier C, Wagener MM, Singh N (2000) Adherence to protease inhibitor therapy and outcomes in patients with HIV infection. Ann Intern Med 133: 21-30.

29. Palella Jr. FJ, Delaney KM, Moorman AC, Loveless MO, Fuhrer J, Satten GA, Aschman DJ, Holmberg SD (1998) Declining morbidity and mortality among patients with advanced human immunodeficiency virus infection. HIV Outpatient Study Investigators. N Engl J Med 338: 853-860.

30. Joint United Nations Programme on HIV/AIDS (2011) UNAIDS Data Tables. Available: http://www.unaids.org/en/media/unaids/contentassets/docume nts/unaidspublication/2011/JC2225_UNAIDS_datatables_en. pdf. Accessed 15 August 2012.

31. World Health Organization (2011) Global HIV/AIDS Response: Epidemic update and health sector progress towards Universal Access: Progress Report 2011, Geneva. Available:

http://www.who.int/hiv/pub/progress_report2011/en/. Accessed 15 August 2012.

32. Gruskin S, Tarantola D (2008) Universal Access to HIV prevention, treatment and care: assessing the inclusion of human rights in international and national strategic plans. Aids 22 Suppl 2: S123-132.

33. Kelly JA, Somlai AM, Benotsch EG, Amirkhanian YA, Fernandez MI, Stevenson LY, Sitzler CA, McAuliffe TL, Brown KD, Opgenorth KM (2006) Programmes, resources, and needs of HIV-prevention nongovernmental organizations (NGOs) in Africa, Central/Eastern Europe and Central Asia, Latin America and the Caribbean. AIDS Care 18: 12-21.

34. Laing R, Davey S, and Hardon A (2006) From Access to Adherence: The Challenges of Antiretroviral Treatment. University of Amsterdam, World Health Organization.

35. The World Health Organization (2010) Antiretroviral therapy for HIV infection in adults and adolescents, Available: http://www.who.int/hiv/pub/arv/adult2010/en/. Accessed 28 August 2012.

36. United Nations Albania: Tirana (2009) Access to HIV Information and Treatment, Care and Support for People Living with HIV is a Human Right. Availabile: http://www.un.org.al/subindex.php?faqe=news\&newsid=195. Accessed 28 July 2010.
37. The World Health Organization (2008) Towards Universal Access: Scaling up priority HIV/AIDS interventions in the health sector. Available: http://www.who.int/hiv/pub/2008progressreport/en/. Accessed 28 July 2010.

38. Montaner JS, Hogg R, Wood E, Kerr T, Tyndall M, Levy AR, Harrigan PR (2006) The case for expanding access to highly active antiretroviral therapy to curb the growth of the HIV epidemic. Lancet 368: 531-536.

39. Bangsberg DR, Hechi FM, Charlebois ED, Zolopa AR, Holodniy M, Sheiner L, Bamberger JD, Chesney MA, Moss A (2000) Adherence to protease inhibitors, HIV-1 viral load, and development of drug resistance in an indigent population. Aids 1: 357-366.

40. Bangsberg DR, Perry S, Charlebois ED, Clark RA, Roberston M, Zolopa AR, Bamberger JD, Chesney MA, Moss A (2001) Non-adherence to highly active antiretroviral therapy predicts progression to AIDS. Aids 15: 1181-1183.

41. Stanojevic M, Alexiev I, Beshkov D, Gokengin D, Mezei M, Minarovits J, Otelea D, Paraschiv S, Poljak M, Zidovec-Lepej S, Paraskevis D (2012) HIV1 molecular epidemiology in the Balkans: a melting pot for high genetic diversity. AIDS reviews 14: 28-36.

42. Carlucci JG, Kamanga A, Sheneberger R, Shepherd BE, Jenkins CA, Spurrier J, Vermund SH (2008) Predictors of adherence to antiretroviral therapy in rural Zambia. J Acquir Immune Defic Syndr 47: 615-622.

43. Johnson MO, Chesney MA, Goldstein RB, Remien RH, Catz S, Gore-Felton C, Charlebois E, Morin SF (2006) Positive provider interactions, adherence self-efficacy, and adherence to antiretroviral medications among HIV-infected adults: A mediation model. AIDS Patient Care STDS 20: 258-268.

44. Laine C, Newschaffer CJ, Zhang D, Cosler L, Hauck WW, and Turner BJ (2000) Adherence to antiretroviral therapy by pregnant women infected with human immunodeficiency virus: a pharmacy claims-based analysis. Obstet Gynecol 95: 167-173.

45. Chesney MA (2000) Factors affecting adherence to antiretroviral therapy. Clin Infect Dis 30 Suppl 2: S171-176.

46. Singh N, Squier C, Sivek C, Wagener M, Nguyen MH, Yu VL (1996) Determinants of compliance with antiretroviral therapy in patients with human immunodeficiency virus: prospective assessment with implications for enhancing compliance. AIDS Care 8: 261-269.

47. Morrison SD, Banushi VH, Sarnquist C, Gashi VH, Osterberg L, Maldonado Y, Harxhi A (2011) Barriers to care and current medical and social needs of HIV-positive patients in Albania. Cent Eur J Public Health 19: 91-97.

48. Chesney MA, Ickovics JR, Chambers DB, Gifford AL, Neidig J, Zwickl B, Wu AW (2000) Self-reported adherence to antiretroviral medications among participants in HIV clinical trials: the AACTG adherence instruments. Patient Care Committee \& Adherence Working Group of the Outcomes Committee of the Adult AIDS Clinical Trials Group (AACTG). AIDS Care 12: 255-266.

49. Reynolds NR, Sun J, Nagaraja HN, Gifford AL, Wu AW, and Chesney MA (2007) Optimizing measurement of selfreported adherence with the ACTG Adherence Questionnaire: a cross-protocol analysis. J Acquir Immune Defic Syndr 46: 402-409. 
50. Weiser S, Wolfe W, Bangsberg D, Thior I, Gilbert P, Makhema J Kebaabetswe P, Dickenson D, Mompati K, Essex M, Marlink R (2003) Barriers to antiretroviral adherence for patients living with HIV infection and AIDS in Botswana. J Acquir Immune Defic Syndr 34: 281-288.

51. Simoni JM, Kurth AE, Pearson CR, Pantalone DW, Merrill JO, Frick PA (2006) Self-Report Measures of Antiretroviral Therapy Adherence: A Review with Recommendations for HIV Research and Clinical Management. AIDS Behav 10: 227-245.

52. Di Matteo MR (2004) Variations in patients' adherence to medical recommendations: a quantitative review of 50 years of research. Med Care 42: 200-209.

53. Wang H, He G, Li X, Yang A, Chen X, Fennie KP, Williams AB (2008) Self-Reported adherence to antiretroviral treatment among HIV-infected people in Central China. AIDS Patient Care STDS 22: 71-80.

54. Altice FL, Mostashari F, and Friedland GH (2001) Trust and the acceptance of and adherence to antiretroviral therapy. J Acquir Immune Defic Syndr 28: 47-58.

\section{Corresponding author}

Shane D. Morrison

Stanford University School of Medicine

Medical School Office Building, 1265 Welch Road

Stanford, CA, 94305-5404, USA

Phone: 520 850-0495

Email: shanem@stanford.edu

Conflict of interests: No conflict of interests is declared. 


\section{Supplementary Items}

Supplementary Table 1. Associations of adherence of patients receiving antiretroviral medication at UHCT HIV/AIDS Ambulatory Clinic by four-day recall

\begin{tabular}{|c|c|c|c|}
\hline Characteristic & Adherent $(n=63)$ & Non-Adherent $(n=5)$ & $P$ Value \\
\hline Age, mean (SD), $y$ & $39.9(11.6)$ & $44.4(13.1)$ & \multirow{2}{*}{0.52} \\
\hline Median (Range), $y$ & $39(18-79)$ & $45(31-64)$ & \\
\hline Female, No. $(\%)$ & $23(36.5)$ & $0(0.0)$ & 0.16 \\
\hline Heterosexual, No. (\%) & $59(93.7)$ & $4(80.0)$ & 0.33 \\
\hline Married, No. (\%) & $30(47.6)$ & $4(80.0)$ & 0.36 \\
\hline Partnered, No. (\%) & $30(47.6)$ & $5(100.0)$ & 0.05 \\
\hline$>$ Higher (12 Classes), No. (\%) & $10(15.9)$ & $0(0.0)$ & 1.00 \\
\hline Muslim, No. (\%) & $51(81.0)$ & $4(80.0)$ & 1.00 \\
\hline Years abroad, mean (SD), $y$ & $2.5(4.6)$ & $6.2(6.5)$ & \multirow{2}{*}{0.04} \\
\hline Median (Range), $y$ & $0(0-17)$ & $3(0-15)$ & \\
\hline Obtained ART abroad, No. (\%) & $3(4.8)$ & $2(40.0)$ & 0.04 \\
\hline Years since diagnosis, mean (SD), $y$ & $2.5(2.7)$ & $6.2(5.8)$ & \multirow{2}{*}{0.03} \\
\hline Median (Range), $y$ & $2(0-13)$ & $5(2-16)$ & \\
\hline Employed/Student/Retired, No. (\%) & $28(44.4)$ & $3(60.0)$ & 0.65 \\
\hline Arrested $\geq 24$ hours, No. (\%) & $14(22.2)$ & $3(60.0)$ & 0.10 \\
\hline Ever tried drugs, No. $(\%)^{*}$ & $6(9.7)$ & $0(0.0)$ & 1.00 \\
\hline Attained HIV through sexual contact, No. (\%) & $31(49.2)$ & $1(20.0)$ & 0.36 \\
\hline Experienced anxiety after HIV diagnosis, No. (\%) & $53(84.1)$ & $3(60.0)$ & 0.21 \\
\hline Experienced depression after HIV diagnosis, No. $(\%) \dagger$ & $40(65.6)$ & $3(60.0)$ & 1.00 \\
\hline Living with household members with HIV, No. $(\%) \dagger$ & $11(17.8)$ & $2(40.0)$ & 0.25 \\
\hline Barrier Index $\downarrow$, mean (SD), \# & $7.7(3.0)$ & $9(2.3)$ & \multirow{2}{*}{0.44} \\
\hline Median (Range), \# & $8(1-13)$ & $8(7-12)$ & \\
\hline Need Index $\S$, mean (SD), \# & $6.1(2.6)$ & $6.4(2.7)$ & \multirow{2}{*}{0.70} \\
\hline Median (Range), \# & $7(0-9)$ & $8(3-9)$ & \\
\hline
\end{tabular}

Supplementary Table 2. Months without therapy of patients missing $>1$ month of therapy at UHCT HIV/AIDS Ambulatory Clinic*

\begin{tabular}{lc}
\hline Measure & Months (n=23†) \\
\hline Months without ART, mean (SD), months & $10.4(4.4)$ \\
Median (Range), months & $10(1-16)$ \\
Months without ART, mean (SD), months $\ddagger$ & $10.4(4.8)$ \\
Median (Range), months $\$$ & $11(1-16)$ \\
\hline
\end{tabular}

*Data is from the dates $1 / 1 / 2008-8 / 1 / 2009$.

$\dagger$ Four of the patients left therapy due to moving to another country.

$\ddagger$ The four patients that moved were removed from the calculation. 
Supplementary Table 3A. Barriers to adherence to ART experienced by patients receiving HIV/AIDS medical care at UHCT HIV/AIDS Ambulatory Clinic

\begin{tabular}{lc}
\hline Barrier & Population (n=68) \\
\hline Simply forgot & $14(20.6)$ \\
Were away from home & $12(17.6)$ \\
Were busy with other things & $12(17.6)$ \\
Ran out of pills & $10(14.7)$ \\
Had a change in daily routine & $9(13.2)$ \\
Felt like the drug was harmful/toxic & $5(7.4)$ \\
Fell asleep/slept through dose time & $5(7.4)$ \\
Did not want others to notice me taking medication & $4(5.9)$ \\
Felt ill or sick & $4(5.9)$ \\
Felt better & $4(5.9)$ \\
Wanted to avoid side effects & $3(4.4)$ \\
Had problems taking pills at specified times (with meals, on an empty stomach, etc.) & $2(2.9)$ \\
Had too many pills to take & $1(1.5)$ \\
Felt depressed/overwhelmed & $1(1.5)$ \\
\hline
\end{tabular}

Supplementary Table 3B. Most difficult barriers to adherence to ART experienced by patients receiving HIV/AIDS medical care at UHCT HIV/AIDS Ambulatory Clinic

\begin{tabular}{lc}
\hline Barrier & Population $(\mathbf{n}=\mathbf{2 3 *})$ \\
\hline Was busy with other things, No. (\%) & $4(17.4)$ \\
Wanted to eliminate side effects, No. (\%) & $3(13.0)$ \\
Ran out of medication, No. (\%) & $3(13.0)$ \\
Simply forgot, No. (\%) & $3(13.0)$ \\
Felt sick, No. (\%) & $2(8.7)$ \\
Did not want others to see my medication, No. (\%) & $2(8.7)$ \\
Felt depressed/overwhelmed, No. (\%) & $2(8.7)$ \\
Was away from home, No. (\%) & $2(8.7)$ \\
Felt better, No. (\%) & $1(4.3)$ \\
Fell asleep/slept through dosing time, No. (\%) & $1(4.3)$ \\
\hline
\end{tabular}

*Some patients responded with more than one barrier that was the most difficult to overcome. 
Supplementary Table 4A. Patient reported interventions to increase adherence of patients receiving HIV/AIDS medical care at UHCT HIV/AIDS Ambulatory Clinic

\begin{tabular}{lc}
\hline Intervention & Population (n=68) \\
\hline More education on the seriousness of HIV/AIDS, No. $(\%)^{*}$ & $25(37.3)$ \\
More education on the reasons for taking medication, No. $(\%)^{*}$ & $22(32.8)$ \\
Not so many pills to take, No. (\%)* & $17(25.4)$ \\
Having a reminder of when to take medication, No. $(\%)$ & $13(19.1)$ \\
Could get medication for free near home, No. (\%) & $13(19.1)$ \\
\hline *67 Respondents &
\end{tabular}

*67 Respondents

Supplementary Table 4B. Most important patient reported interventions to increase adherence of patients receiving HIV/AIDS medical care at UHCT HIV/AIDS Ambulatory Clinic

\begin{tabular}{lc}
\hline Intervention & Population (n=57*) \\
\hline More education of the reasons for taking medication, No. (\%) & $17(29.8)$ \\
Could get medication for free near home, No. (\%) & $12(21.1)$ \\
More education on the seriousness of HIV/AIDS, No. (\%) & $10(17.5)$ \\
Having a reminder of when to take medication, No. (\%) & $10(17.5)$ \\
Not so many pills to take, No. (\%) & $6(10.5)$ \\
Better quality medications in Albania, No. (\%) & $2(3.5)$ \\
\hline *Som)
\end{tabular}

*Some patients responded with more than one suggestion of an intervention. 


\section{Appendix 1.}

1. Taking all of your HIV medication is difficult. Below asks about the medications that you may have MISSED taking over the last four days. If you did not miss any doses, write a zero (0) in the box. Note that the table asks about DOSES not PILLS. If you took only a portion of a dose on one or more of these days, please report the dose(s) as being missed. See page 4 for current medication doses.

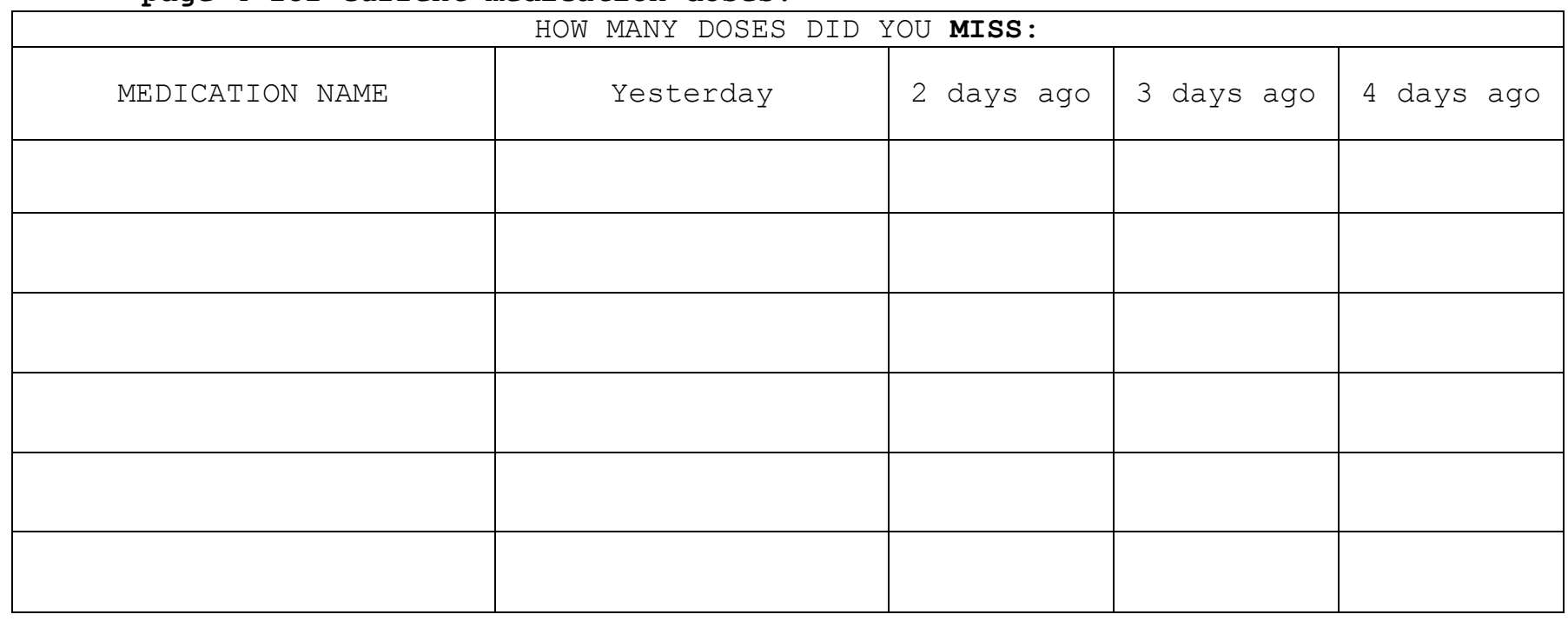

2. Most medications need to be taken on a schedule, such as "2 times a day" or "3 times a day" or "every 8 hours." How closely did you follow your specific schedule over the last four days?

$\square$ Never

$\square$ Some of the time

$\square$ About half of the time

$\square$ Most of the time

$\square$ All of the time

3. Do any of your medications have special instructions, such as "take with food" or "on an empty stomach" or "with plenty of fluids"?

$\square$ Yes

$\square$ No

B) If yes, how often did you follow those special instructions over the last four days?

$\square$ Never

$\square$ Some of the time

$\square$ About half of the time

$\square$ Most of the time

$\square$ All of the time

4. When was the last time you missed ANY of your medications?

$\square$ Within past 2 days

$\square$ Within past 2 weeks

$\square$ 2-4 weeks ago

$\square$ 1-3 months ago

$\square$ More than 3 months ago

$\square$ Never skip medications 


\section{Appendix 2.}

1. Currently or in the past 12 months, have you needed any of these services related to your HIV/AIDS infection?:

\begin{tabular}{|c|c|c|}
\hline & $\begin{array}{l}\text { Have you needed this } \\
\text { service in the past } 12 \\
\text { months? }\end{array}$ & $\begin{array}{c}\text { If yes, Have you been } \\
\text { able to get this } \\
\text { service in the past } \\
12 \text { months? }\end{array}$ \\
\hline HIV medical services & $\begin{array}{c}\square \text { Yes } \\
\square \text { No } \\
\square \text { Don't know what this } \\
\text { means }\end{array}$ & $\begin{array}{l}\square \text { Yes } \\
\square \quad \text { No }\end{array}$ \\
\hline $\begin{array}{c}\text { Psychologist or } \\
\text { psychiatric services }\end{array}$ & $\begin{array}{c}\square \text { Yes } \\
\square \text { No } \\
\square \text { Don't know what this } \\
\text { means }\end{array}$ & $\begin{array}{l}\square \text { Yes } \\
\square \quad \text { No }\end{array}$ \\
\hline $\begin{array}{c}\text { Assistance in finding a } \\
\text { doctor for ongoing } \\
\text { medical services }\end{array}$ & $\begin{array}{c}\square \text { Yes } \\
\square \text { No } \\
\square \text { Don't know what this } \\
\text { means }\end{array}$ & $\begin{array}{l}\square \text { Yes } \\
\square \quad \text { No }\end{array}$ \\
\hline $\begin{array}{l}\text { Assistance in finding } \\
\text { shelter or housing }\end{array}$ & $\begin{array}{c}\square \text { Yes } \\
\square \text { No } \\
\square \text { Don't know what this } \\
\text { means }\end{array}$ & $\begin{array}{l}\square \text { Yes } \\
\square \quad \text { No }\end{array}$ \\
\hline $\begin{array}{c}\text { Assistance with finding } \\
\text { meals or food }\end{array}$ & $\begin{array}{c}\square \text { Yes } \\
\square \text { No } \\
\square \text { Don't know what this } \\
\text { means }\end{array}$ & $\begin{array}{l}\square \text { Yes } \\
\square \quad \text { No }\end{array}$ \\
\hline $\begin{array}{c}\text { Assistance with } \\
\text { completing daily } \\
\text { activities or chores }\end{array}$ & $\begin{array}{c}\square \text { Yes } \\
\square \text { No } \\
\square \text { Don't know what this } \\
\text { means }\end{array}$ & $\begin{array}{l}\square \text { Yes } \\
\square \quad \text { No }\end{array}$ \\
\hline $\begin{array}{l}\text { Transportation } \\
\text { assistance }\end{array}$ & $\begin{array}{c}\square \text { Yes } \\
\square \text { No } \\
\square \text { Don't know what this } \\
\text { means }\end{array}$ & $\begin{array}{l}\square \text { Yes } \\
\square \quad \text { No }\end{array}$ \\
\hline Childcare assistance & $\begin{array}{c}\square \text { Yes } \\
\square \text { No } \\
\square \text { Don't know what this } \\
\text { means }\end{array}$ & $\begin{array}{l}\square \text { Yes } \\
\square \quad \text { No }\end{array}$ \\
\hline $\begin{array}{l}\text { Education or information } \\
\text { on HIV risk prevention }\end{array}$ & $\begin{array}{c}\square \text { Yes } \\
\square \text { No } \\
\square \text { Don't know what this } \\
\text { means }\end{array}$ & $\begin{array}{l}\square \text { Yes } \\
\square \quad \text { No }\end{array}$ \\
\hline
\end{tabular}


2. Below is a list of problems that you may have had when trying to get or use HIV/AIDS medical services. If you experienced any of the following problems, mark "Yes." If you did not have any of the problems did not affect you, mark "No." If you do not know if the problem affected you, mark "Don't Know." Did not know where I could find medical help for HIV/AIDS Too sick to get medical help

Did not think that HIV/AIDS required medical help

Mental problems (like depression, anxiety, dementia, etc.) kept me from getting medical help for HIV/AIDS

People at the hospital or clinic made me feel worse about

myself for having HIV/AIDS

$\begin{array}{ccc}\square & \square & \square \\ \square & \square & \square \\ \square & \square & \square \\ \square & \square & \square\end{array}$
of my HIV/AIDS

\begin{tabular}{cc}
\hline My doctor or nurse did not know about HIV/AIDS & $\square$ \\
\hline I had to wait too long to see a doctor for HIV/AIDS & $\square$ \\
\hline I was afraid to get in trouble with the law and/or police & $\square$ \\
\hline Did not want people to know I had HIV/AIDS & $\square$ \\
\hline w was afraid I would lose my job and/or house because of & $\square$ \\
HIV/AIDS & $\square$ \\
\hline No transportation available & $\square$ \\
\hline No childcare available & $\square$ \\
\hline was not eligible for the HIV/AIDS medical help & $\square$ \\
\hline There was too much paperwork & $\square$ \\
\hline The services cost too much money & $\square$ \\
\hline There are too many instructions I have to follow & $\square$ \\
\hline Other (specify) & $\square$ \\
\hline
\end{tabular}

